\title{
GABAergic Neurons that Contain Neuropeptide Y Selectively Target Cells with the Neurokinin 1 Receptor in Laminae III and IV of the Rat Spinal Cord
}

\author{
Erika Polgár, Safa A. S. Shehab, Christine Watt, and Andrew J. Todd \\ Laboratory of Human Anatomy, Institute of Biomedical and Life Sciences, University of Glasgow, Glasgow G12 8QQ, \\ United Kingdom
}

Neuropeptide $Y$ (NPY) is contained in a population of GABAergic interneurons in the spinal dorsal horn and, when administered intrathecally, can produce analgesia. We previously identified a strong monosynaptic link between substance P-containing primary afferents and cells in lamina III or IV with the neurokinin 1 (NK1) receptor. Because some of these cells belong to the spinothalamic tract, they are likely to have an important role in pain mechanisms.

In this study, we used confocal microscopy to examine the input to lamina III/IV NK1 receptor-immunoreactive neurons from NPY-containing axons. All of the cells studied received a dense innervation from NPY-immunoreactive axons, and electron microscopy revealed that synapses were often present at points of contact. Most NPY-immunoreactive boutons were also GABAergic, which supports the suggestion that they are derived from local neurons. The association between NPYcontaining axons and NK1 receptor-immunoreactive neurons was specific, because postsynaptic dorsal column neurons (which were located in laminae III-V but did not possess NK1 receptors) and lamina I neurons with the NK1 receptor received significantly fewer contacts from NPY-immunoreactive axons. In addition, the NK1 receptor-immunoreactive lamina III/IV cells received few contacts from nitric oxide synthase-containing axons (which belong to a different population of GABAergic dorsal horn neurons). The NPY-containing axons appeared to be targeted to the NK1 receptor-immunoreactive neurons themselves rather than to their associated substance P-immunoreactive inputs.

The dense innervation of these cells by NPY-containing axons suggests that they may possess receptors for NPY and that activation of these receptors may contribute to NPY-mediated analgesia.

Key words: neuropeptide Y; substance $P$ receptor; confocal microscopy; electron microscopy; volume transmission; GABA
A plexus of neuropeptide Y (NPY)-containing axons has been described in the dorsal horn of the spinal cord in several mammalian species (Hökfelt et al., 1981; Hunt et al., 1981; Gibson et al., 1984; Sasek and Elde, 1985; Krukoff, 1987; Doyle and Maxwell, 1994). Although NPY is present in descending noradrenergic axons that terminate in the lateral horn in thoracic segments (Blessing et al., 1987; Patel et al., 1997), NPY-containing axons in the dorsal horn do not contain noradrenaline and are thought to be derived from local GABAergic interneurons with cell bodies in laminae I-III (Rowan et al., 1993).

Intrathecal administration of NPY to rats can produce analgesia and suppress the flexion reflex at doses that do not interfere with motor behavior (Hua et al., 1991; Xu et al., 1994). There are several lines of evidence to suggest that at least part of this effect is mediated by an inhibitory action on nociceptive primary afferents. Some NPY-binding sites in the rat dorsal horn disappear after neonatal capsaicin treatment, dorsal rhizotomy, or peripheral nerve section, which suggests that NPY receptors are present on small-diameter primary afferents (Kar and Quirion, 1992).

\footnotetext{
Received Sept. 15, 1998; revised Dec. 1, 1998; accepted Jan. 16, 1999.

The work was supported by grants from the Wellcome Trust, which are gratefully acknowledged. The work was performed while E.P. was on study leave from the Department of Anatomy, Histology, and Embryology, University Medical School of Debrecen, Nagyerdei körút 98, Debrecen H-4012, Hungary. We thank Drs. S. Vigna, D. V. Pow, and P. C. Emson for gifts of antisera, and Drs. A. P. Payne and D. J. Maxwell for helpful discussion.

Correspondence should be addressed to Dr. A. J. Todd, Laboratory of Human Anatomy, University of Glasgow, Glasgow G12 8QQ, United Kingdom.

Copyright (C) 1999 Society for Neuroscience $\quad 0270-6474 / 99 / 192637-10 \$ 05.00 / 0$
}

NPY can reduce $\mathrm{Ca}^{2+}$ conductance in cultured rat dorsal root ganglion neurons and inhibit their potassium-evoked release of substance P (Walker et al., 1988; Bleakman et al., 1991). In addition, studies in the cat spinal cord with antibody microprobes have demonstrated that NPY microinjected into the superficial dorsal horn reduces the release of substance $\mathrm{P}$ produced by peripheral nerve stimulation at $\mathrm{C}$ fiber strength (Duggan et al., 1991).

Substance $\mathrm{P}$ is present in many small-diameter primary afferents that terminate in the superficial dorsal horn, and all of these appear to function as nociceptors (Lawson et al., 1997). We have demonstrated recently that one of the major targets of substance $\mathrm{P}$-containing primary afferents is a population of neurons that possess the neurokinin 1 (NK1) receptor (on which substance $\mathrm{P}$ acts) and have cell bodies in lamina III or IV and long dorsally directed dendrites that penetrate the superficial laminae (Naim et al., 1997). Some of these cells belong to the spinothalamic tract (Marshall et al., 1996) and therefore provide a strong disynaptic link between nociceptive primary afferents and the thalamus (Naim et al., 1997), which is likely to be important in spinal pain processing.

In this study, we tested for an association between NPYcontaining axons and lamina III/IV NK1 receptor-immunoreactive neurons that might contribute to NPY-induced analgesia. We examined the specificity of this association in two ways. First, we compared it with that between NPY-immunoreactive axons and two other neuronal populations: lamina I neurons with NK1 receptors and postsynaptic dorsal column (PSDC) neurons (which 

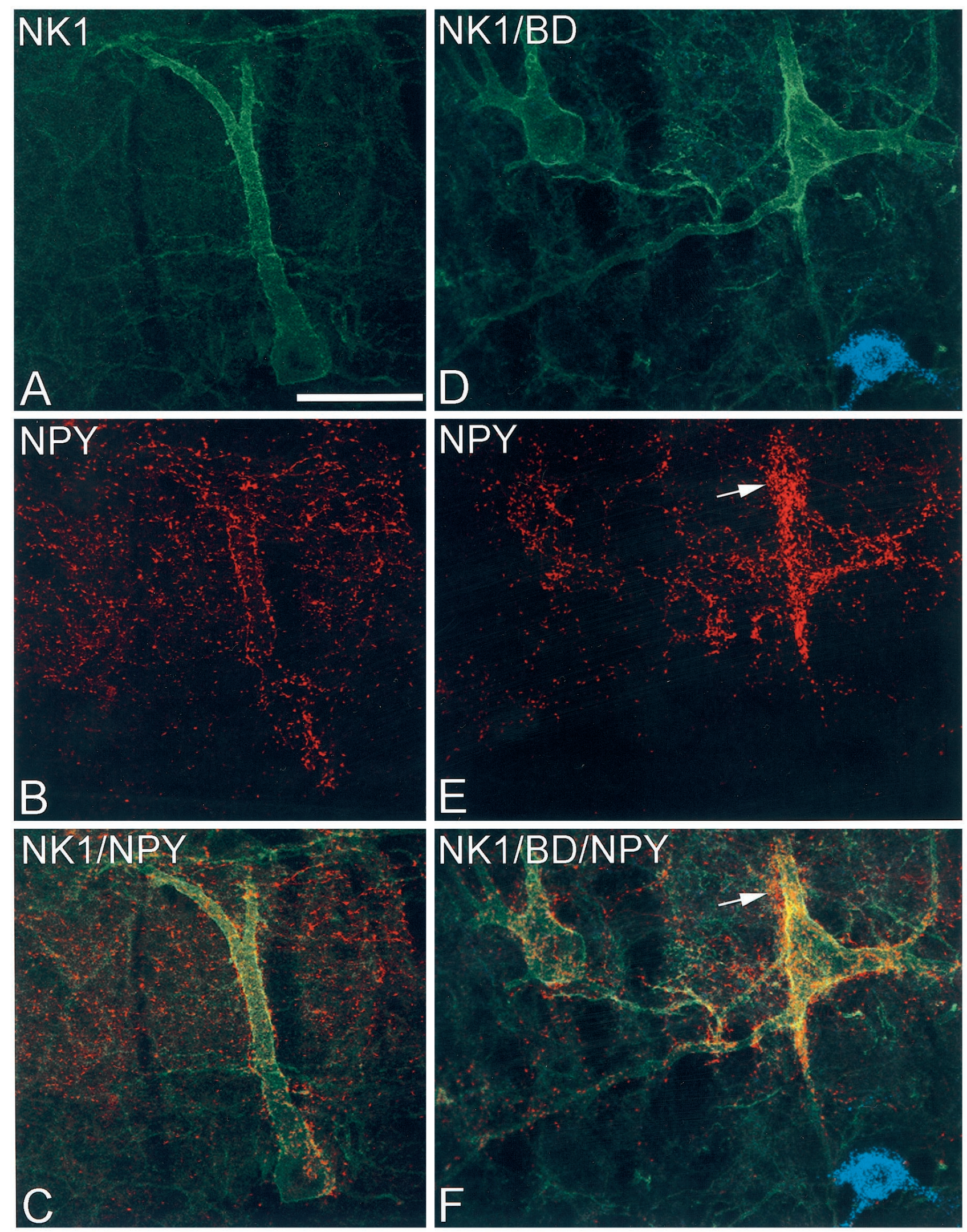

Figure 1. Confocal images from parasagittal sections showing NPY-immunoreactive axons (red), lamina III NK1 receptor-immunoreactive neurons (green), and a PSDC cell (blue). A, An NK1 receptor-immunoreactive neuron has a long dorsal dendrite that extends up through the superficial laminae and bifurcates. $B$, The same field scanned to reveal NPY shows a plexus of immunoreactive axons in the superficial dorsal horn, as well as rows of immunoreactive axons in a position corresponding to the dorsal dendrite of the NK1 receptor-immunoreactive neuron. $C$, The association can be seen clearly when the two color images are merged. In this case, there are numerous contacts from NPY-immunoreactive axons onto (Figure legend continues) 
did not possess the NK1 receptor). Second, we looked for contacts between lamina III/IV NK1 receptor-immunoreactive cells and axons belonging to a different population of GABAergic neurons, those which contain nitric oxide synthase (NOS). We also used electron microscopy to confirm that the NPY-immunoreactive axons contained GABA and to determine whether they formed synapses with the NK1 receptor-immunoreactive neurons.

\section{MATERIALS AND METHODS}

Animals. Eight adult Albino-Swiss rats (either sex; 220-370 gm; Glasgow University, Glasgow, United Kingdom) were used in this study. Six rats were deeply anesthetized and perfused through the left cardiac ventricle with a fixative containing either $4 \%$ (freshly depolymerized) formaldehyde $(n=4)$ or $1 \%$ formaldehyde $-1 \%$ glutaraldehyde $(n=2)$. Two additional rats were anesthetized with halothane and received a stereotaxic injection of 50 or $100 \mathrm{nl}$ of $20 \%$ biotin-dextran (BD) (Sigma, Poole, Dorset, UK) into the left gracile nucleus. Three or $8 \mathrm{~d}$ later, they were deeply anesthetized and perfused with $4 \%$ formaldehyde.

Material from rats perfused with $4 \%$ formaldehyde was processed for immunofluorescence and examined with confocal microscopy, whereas that from rats fixed with glutaraldehyde underwent combined preembedding and postembedding immunocytochemistry and was examined with electron microscopy. Vibratome sections (70- $\mu$ m-thick) were cut from midlumbar segments, treated with $50 \%$ ethanol for 30 min to enhance antibody penetration, and processed for immunocytochemistry. Tissue for electron microscopy was also treated with $1 \%$ sodium borohydride for $30 \mathrm{~min}$ to reduce the effects of glutaraldehyde on immunostaining. Parasagittal sections were used for confocal microscopy, because these are better for revealing the dendritic trees of lamina III/IV NK1 receptor-immunoreactive neurons. However, tissue for electron microscopy was cut into transverse sections, because these allow complete penetration of antibodies, which is otherwise limited in the absence of Triton X-100 (Llewellyn-Smith and Minson, 1992).

Immunofluorescence and detection of retrogradely transported $B D$. Double- or triple-labeling immunofluorescence histochemistry was performed as described previously (Naim et al., 1997), with various combinations of primary antibodies. Sections from the four rats that were fixed with $4 \%$ formaldehyde and had not received injections of BD were incubated for $3 \mathrm{~d}$ with one of the following combinations: (1) anti-NK1 receptor (raised in rabbit or guinea pig, diluted $1: 10,000$ or $1: 1000$, respectively), goat or rabbit antiserum against NPY (both diluted 1:1000; Affiniti, Exeter, UK and Peninsula Laboratories, Belmont, CA, respectively) and in some cases also rat monoclonal antibody raised against substance P (diluted 1:200; Sera-Lab, Crawley Down, UK); or (2) antiNK1 receptor (raised in rabbit or guinea pig) and sheep antiserum against neuronal NOS (diluted 1:2000) (Herbison et al., 1996). After rinsing, the sections were then incubated for 1-2 $\mathrm{hr}$ in species-specific secondary antibodies (anti-IgG; all raised in donkey and diluted 1:100; Jackson ImmunoResearch, West Grove, PA), which were conjugated to one of the following dyes: fluorescein isothyocyanate, lissamine rhodamine, or cyanine-5.18. Antibodies were made up in PBS containing $0.3 \%$ Triton X-100.

Sections from the rats that had received injections of $\mathrm{BD}$ into the gracile nucleus were reacted as described above with antibodies against the NK1 receptor (raised in rabbit or guinea pig) and NPY (raised in goat or rabbit), which were revealed with secondary antibodies conjugated to fluorescein and cyanine-5.18. The sections were also incubated in avidin-rhodamine (diluted 1:500; Jackson ImmunoResearch) to reveal retrogradely transported BD in PSDC cells. Transverse vibratome sections $(100-\mu \mathrm{m}$-thick) through the injection sites from these rats were processed with avidin-horseradish peroxidase (diluted 1:1000; Sigma) and diaminobenzidine (DAB) to reveal the extent of spread of tracer.
Confocal microscopy and analysis. Sections were examined with a Bio-Rad (Hemel Hempstead, UK) MRC 1024 confocal scanning laser microscope with a Krypton-Argon laser (Naim et al., 1997, 1998). NK1 receptor-immunoreactive neurons with cell bodies located $>150 \mu \mathrm{m}$ below the dorsal white matter (in lamina III or IV) and dendrites that could be traced into lamina II were selected for further study. The association between NPY-immunoreactive boutons and lamina III/IV NK1 receptor-immunoreactive neurons was examined on at least 50 cells in sections from all six rats used for confocal microscopy. Fifteen neurons (five each from three animals) were selected for detailed quantitative analysis of contacts. The selection of cells was made before NPY immunoreactivity was examined to avoid bias toward neurons with a high density of contacts. The fifteen cells were first drawn with a computer drawing program from confocal z-series of scans to reveal NK1 receptor immunoreactivity. Sequential scans obtained with a $40 \times$ oil-immersion lens were then used to reveal the positions of contacts from NPYimmunoreactive varicosities onto their cell bodies and dendrites, and these were recorded and plotted onto the drawings. The frequency of NPY contacts per unit length of dendrite for each of these cells was determined by measuring the length of each dendrite from z-series with Neurolucida for Confocal (MicroBrightField Inc., Colchester, VT) as described previously (Naim et al., 1998). Because the density of NPY boutons is higher in the superficial dorsal horn than in deeper laminae, we determined the density of contacts separately for those dendrites that lay within laminae I and II and for dendrites in deeper laminae. The relationship between the substance P- and NPY-immunoreactive boutons that were associated with NK1 receptor-immunoreactive neurons was examined by scanning parts of the dendritic trees and cell bodies of at least 20 such neurons (from two rats) with a $40 \times$ oil-immersion lens.

For comparison, a similar analysis of NPY contacts onto lamina I cells with the NK1 receptor was also performed. Fifteen such cells (five each from three animals) were selected and drawn as described above. The positions of contacts formed by NPY-immunoreactive varicosities were then plotted onto the drawings of the cells, and the density of contacts onto their dendrites was calculated. To determine whether NPY boutons were associated with the cell bodies of PSDC neurons in laminae III-V, 25 retrogradely labeled cells were examined from each of the two rats in which BD had been injected into the gracile nucleus. The number of contacts that the cell bodies received from NPY-immunoreactive varicosities was determined for each of these cells. No attempt was made to quantify contacts on dendrites, because dendritic filling with BD was clearly incomplete.

The association between laminae III/IV NK1 receptorimmunoreactive neurons and NOS-immunoreactive varicosities was examined quantitatively for six neurons (three each from two rats). Again, the number of contacts onto cell bodies was counted, and the density of contacts onto dendrites in superficial laminae (I and II) and deeper laminae was determined by measuring lengths of the dendrites with Neurolucida for Confocal software.

Electron microscopy. Transverse sections from the rats fixed with glutaraldehyde-formaldehyde were processed by a double-labeling preembedding method (Todd et al., 1996) to reveal NK1 receptor with immunoperoxidase-DAB and NPY with silver-intensified immunogold. The sections were incubated for $3 \mathrm{~d}$ in a mixture of guinea pig anti-NK1 receptor $(1: 5000$ or $1: 10,000)$ and rabbit anti-NPY $(1: 10,000$ or $1: 20,000)$ and then overnight in biotinylated donkey anti-guinea pig $\operatorname{IgG}(1: 500$; Jackson ImmunoResearch) and goat anti-rabbit IgG coated with $1 \mathrm{~nm}$ gold particles (diluted 1:50; Amersham International, Buckinghamshire, UK). The gold was revealed by silver intensification (IntenSE kit; Amersham International), and sections were subsequently incubated overnight in avidin-horseradish peroxidase (1:1000) that was revealed with DAB. The sections were osmicated $\left(30 \mathrm{~min}\right.$ in $\left.1 \% \mathrm{OsO}_{4}\right)$, dehydrated in acetone, and flat-embedded in Durcupan between acetate foils. Antibod-

\footnotetext{
the dorsal dendrite but relatively fewer onto the cell body. $D$, The cell bodies of two NK1 receptor-immunoreactive neurons are located close to a PSDC neuron that contains biotin-dextran. Although not shown in this field, the dendrites of both NK1 receptor-immunoreactive neurons could be followed dorsally into lamina I. E, The same region scanned to reveal NPY. F, When the three colors are merged, it can be seen that both NK1 receptor-immunoreactive neurons have numerous NPY-immunoreactive boutons associated with them (particularly the cell on the right), whereas very few NPY-immunoreactive boutons are in contact with the PSDC cell. Arrows in $E$ and $F$ show a region where numerous NPY-immunoreactive boutons are associated with the proximal dendrite of the NK1 receptor-immunoreactive neuron, but many of them are not actually in contact with it. $A-C$ are from a section reacted with guinea pig NK1 receptor antiserum and rabbit anti-NPY and were made up from six scans, each separated by $1 \mu \mathrm{m}$. $D-F$ are from a section reacted with rabbit anti-NK1 receptor and goat anti-NPY and are built from 11 scans, each separated by $1 \mu \mathrm{m}$. Scale bar, $50 \mu \mathrm{m}$.
} 

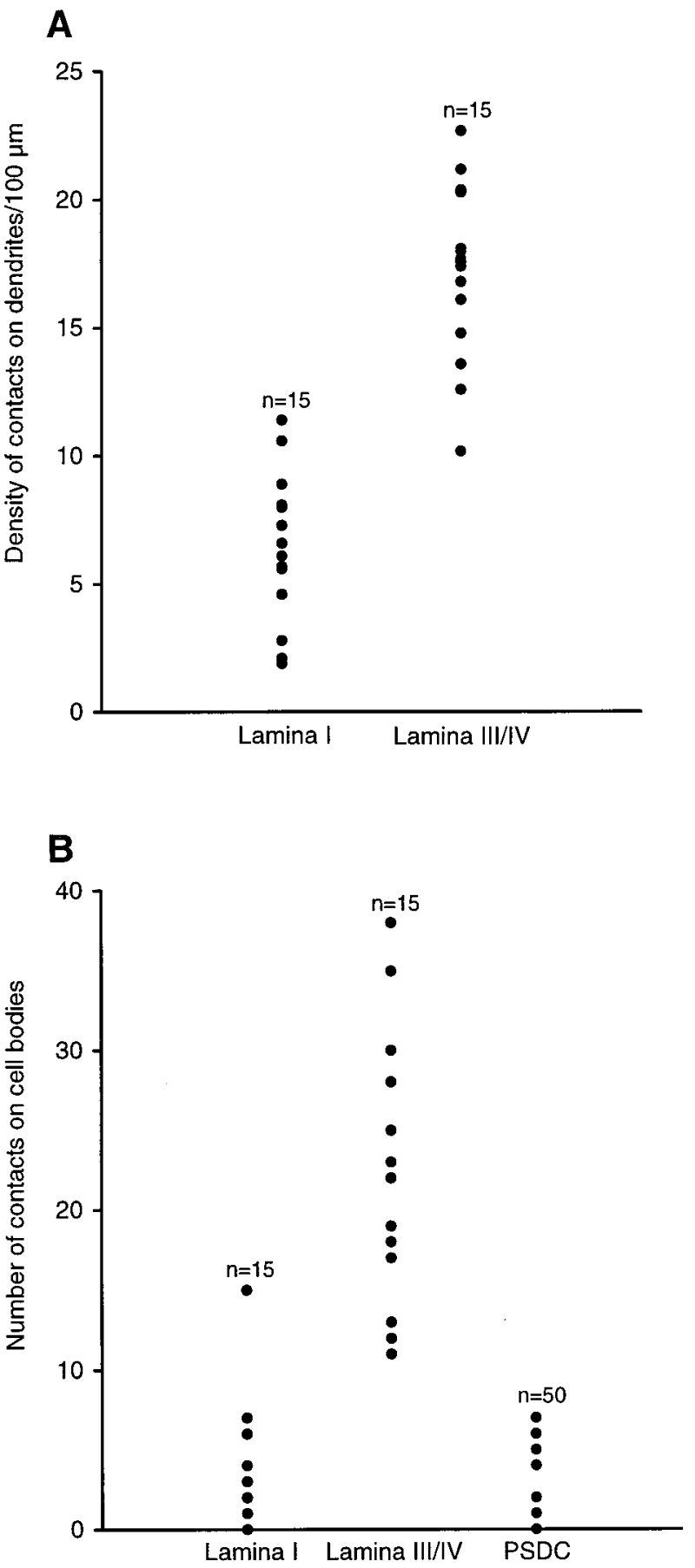

Figure 2. A, A graph showing the density of contacts from NPYimmunoreactive varicosities $/ 100 \mu \mathrm{m}$ of dendrite for 15 neurons in lamina I with the NK1 receptor and for 15 neurons that possessed the receptor and had cell bodies in lamina III or IV. B, A graph showing the numbers of axosomatic contacts from NPY-immunoreactive varicosities onto the cell bodies of the same lamina I and lamina III/IV NK1 receptorimmunoreactive neurons and also onto the cell bodies of 50 PSDC neurons in laminae III-V. The PSDC neurons did not possess the NK1 receptor.

ies used in the preembedding reaction were made up in PBS without Triton X-100.

Two NK1 receptor-immunoreactive neurons with long dorsal dendrites (one from each rat) were selected and drawn with a camera lucida. The cell body of one of these neurons was in lamina III and that of the other was on the border between laminae III and IV. The vibratome

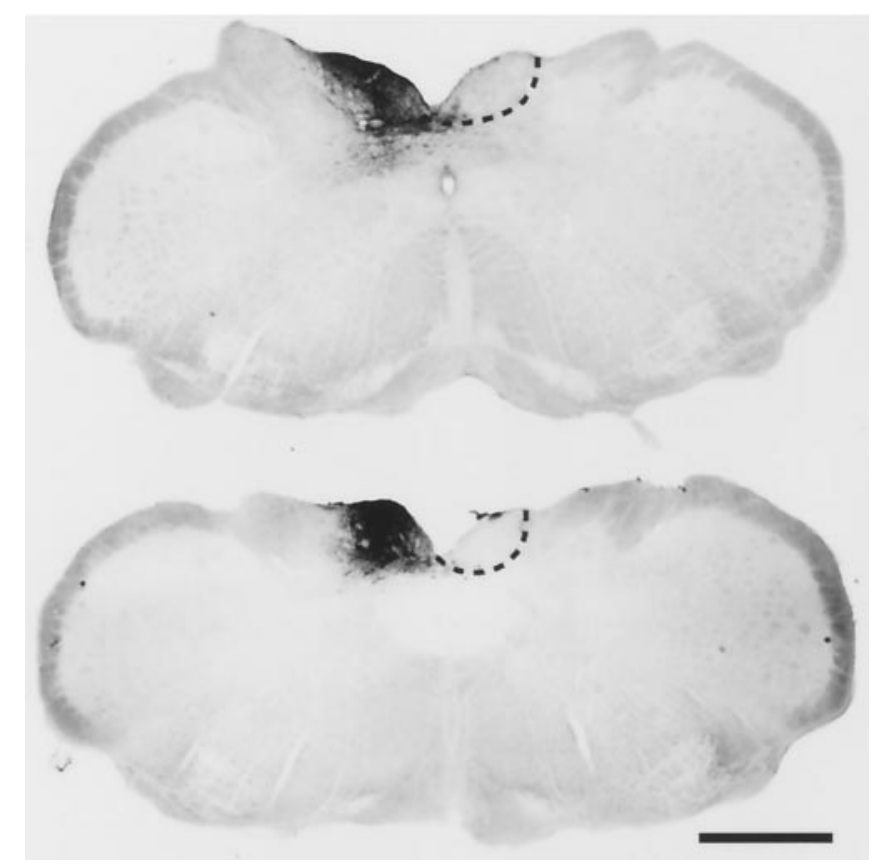

Figure 3. Transverse sections through the injection sites from the two rats in which PSDC cells were labeled. The dense region of DAB reaction product (injection site) fills the gracile nucleus on the left side but does not spread significantly beyond it. The position of the gracile nucleus on the contralateral side is shown with a dashed line. The injections were near the level of the obex in the lower medulla. Scale bar, $1 \mathrm{~mm}$.

sections were then mounted onto blocks of cured resin, and ribbons of ultrathin sections through parts of the cell bodies and dendrites of these neurons were cut with a diamond knife and collected onto Formvarcoated single-slot nickel grids. Every second grid was processed for postembedding immunocytochemistry to reveal GABA-like immunoreactivity, whereas sections on the remaining grids (reference sections) were stained with lead citrate and viewed without any further processing. The grids that were used for postembedding immunocytochemistry contained three sections, whereas the other grids contained two sections. The postembedding reaction for GABA was performed as described previously (Todd et al., 1996), except that the GABA antiserum was used at a dilution of 1:1000, and the secondary antibody (goat anti-rabbit IgG; diluted 1:25; British Biocell International, Cardiff, UK) was adsorbed onto $15 \mathrm{~nm}$ gold particles.

Sections that had not been reacted for GABA were viewed first with the electron microscope (Philips CM100, equipped with specimen relocation software), and NPY-immunoreactive boutons that either contacted the NK1 receptor-immunoreactive neuron or else were close to it $(<10 \mu \mathrm{m}$ apart) were identified. Axonal boutons that contained more than four silver particles on both of the reference sections on a grid were classified as NPY-immunoreactive. Five central axons belonging to type II synaptic glomeruli (Ribeiro-da-Silva and Coimbra, 1982) were also identified on each grid, and these were subsequently used to determine the level of background labeling with the GABA antiserum (see below).

The grids that had been reacted with the GABA antiserum were then examined, and the NPY-immunoreactive boutons and glomerular central axons were identified on the two consecutive serial sections. Gold particles were counted over these axons, and their cross-sectional areas were measured with an image analysis program (KS300; Kontron Elektronik $\mathrm{GmbH}$, München, Germany). For each grid, the mean density of gold particles over the central axons of glomeruli (which are not GABAergic) was determined, and those NPY-immunoreactive boutons that had gold particle densities that exceeded this value by at least three times on both serial sections were defined as GABA-immunoreactive (Bernardi et al., 1995; Todd, 1996). Thirty-five NPY-immunoreactive boutons were tested for GABA immunoreactivity in this way (16 and 19 in sections from the two rats).

Antibodies. The rabbit antiserum to NK1 receptor was donated by Dr. S. Vigna (Durham, NC) and was raised against a synthetic peptide 
corresponding to the 15 amino acids at the $\mathrm{C}$ terminus of the rat $\mathrm{NK} 1$ receptor coupled to bovine thyroglobulin (Vigna et al., 1994). This antibody has been shown to recognize a protein band of $80-90 \mathrm{kDa}$ on Western blots of membranes from cells transfected with the NK1 receptor, and immunostaining can be blocked by addition of the immunizing peptide (Liu et al., 1994; Vigna et al., 1994; Brown et al., 1995).

The guinea pig antiserum against NK1 receptor was raised commercially (Affiniti) against a synthetic peptide with the same sequence (KTMTESSSF YSNMLA) as that used by Vigna et al. (1994). The peptide was conjugated through its $\mathrm{N}$ terminal to keyhole limpet hemocyanin with glutaraldehyde, and three guinea pigs received seven injections of the conjugate over a 12 week period. Serum from all three animals was tested on spinal cord sections (1:1000 for immunofluorescence), and in each case this resulted in specific immunostaining. Serum from one animal (ATD3) was used in this study, because this gave the strongest staining. Specificity was tested by (1) preabsorbing the antiserum with the immunizing peptide for $1 \mathrm{hr}$ before use, (2) replacing it with preimmune serum from the same animal, and (3) performing double immunofluorescence with both rabbit and guinea pig antiserum against NK1 receptor.

We have reported previously that staining with both rabbit and goat antisera against NPY is blocked by preincubation with NPY (Rowan et al., 1993). The substance $P$ antibody (Cuello et al., 1979) recognizes the $\mathrm{C}$-terminal part of the peptide and therefore does not distinguish between substance $\mathrm{P}$ and the related tachykinins neurokinin $\mathrm{A}$ and neurokinin B. For convenience, this type of immunostaining will be referred to as substance P immunoreactivity (for review, see Naim et al., 1997). The GABA antiserum, which was donated by Dr. David Pow (Brisbane, Australia), is highly selective for the fixation products of GABA and does not cross react with those of glycine, taurine, glutamate, glutamine, or aspartate (Pow and Crook, 1993).

\section{RESULTS}

\section{Confocal microscopy}

For all tissue examined in this part of the study, penetration of immunostaining into the vibratome sections appeared to be complete, because no consistent alteration in the density of immunoreactive profiles was seen when the sections were scanned through their full thickness. The pattern of NK1 receptor immunoreactivity with both rabbit and guinea pig antisera was the same and closely resembled that which has been reported previously in the rat spinal cord (Bleazard et al., 1994; Nakaya et al., 1994; Vigna et al., 1994; Brown et al., 1995; Littlewood et al., 1995). Pretreatment of the guinea pig antiserum with the immunizing peptide at $1 \mu \mathrm{g} / \mathrm{ml}$ strongly suppressed the immunoreactivity, and immunostaining was abolished when the concentration of peptide was increased to $10 \mu \mathrm{g} / \mathrm{ml}\left(6 \times 10^{-6} \mathrm{M}\right)$. No staining was seen when the antiserum was replaced with preimmune serum from the same guinea pig. On sections reacted with both guinea pig and rabbit NK1 receptor antisera, the same profiles were stained with each antiserum.

Many NK1 receptor-immunoreactive neurons with cell bodies in lamina III or IV and long dorsally directed dendrites that entered the superficial laminae were observed (Fig. 1A). As described previously, these cells also often had dendrites that remained in the deeper laminae (Brown et al., 1995; Naim et al., 1997, 1998). The distribution of NPY immunoreactivity was also the same as that reported in previous studies in the rat (Hökfelt et al., 1981; Hunt et al., 1981; Sasek and Elde, 1985; Rowan et al., 1993): a dense plexus of NPY-immunoreactive axons was observed in laminae I and II (Fig. 1B); however, axons were also present in deeper laminae, often in the form of discrete clusters.

All of the lamina III/IV NK1 receptor-immunoreactive neurons were associated with numerous NPY-immunoreactive axonal varicosities. These were found to contact not only the dendrites in laminae I and II (where NPY-containing axons are common) but also dendrites in deeper laminae, as well as cell bodies (Fig. 1). In some cases, the density of contacts onto the dendrites was so great that they were completely outlined by NPY-immunoreactive varicosities (Fig. $1 A-C$ ). Although many of the NPY-immunoreactive axons that surrounded the cells appeared to be in direct contact with them, others were separated from the cells by distances of up to $\sim 10 \mu \mathrm{m}$, although they appeared to be specifically associated with them. This latter arrangement was particularly obvious around the cell bodies and proximal dendrites of the neurons, because the density of NPYimmunoreactive axons in laminae III and IV was otherwise much lower (Fig. $1 E, F)$. For the 15 lamina III/IV NK1 receptorimmunoreactive neurons on which quantitative analysis was performed, the density of contacts from NPY-immunoreactive varicosities $/ 100 \mu \mathrm{m}$ of dendrite varied from 10.20 to 22.67 $(17.16 \pm 0.87$, mean \pm SEM) (Fig. $2 A)$. The dorsal dendrites of these neurons that lay within laminae I and II received between 7.79 and 20.07 contacts/100 $\mu \mathrm{m}(15.54 \pm 1.00$, mean $\pm \mathrm{SEM})$, whereas dendrites in deeper laminae received between 14.04 and 36.64 contacts $/ 100 \mu \mathrm{m}(20.55 \pm 1.73$, mean $\pm \mathrm{SEM})$. This difference was significant ( $p<0.05$; paired $t$ test). The cell bodies of these neurons received between 11 and 38 contacts $(22.07 \pm 2.21$, mean \pm SEM) (Fig. 2B).

Examination of NK1 receptor-immunoreactive neurons with cell bodies in lamina I revealed that these cells also received contacts from NPY-immunoreactive varicosities; however, these contacts were generally less numerous on both cell bodies and dendrites than was the case for the lamina III/IV cells (Fig. 2). The dendrites of the 15 lamina I cells that were analyzed quantitatively received between 1.86 and 11.39 contacts $/ 100 \mu \mathrm{m}$ $(6.37 \pm 0.73$, mean \pm SEM $)$, and the cell bodies received between 0 and 15 contacts $(3.53 \pm 0.98$, mean \pm SEM $)$.

The injection sites used to label PSDC cells were restricted to the gracile nucleus (Fig. 3). Numerous retrogradely labeled cell bodies were found, and these were virtually restricted to laminae III-V of the dorsal horn. Between 6 and 13 labeled neurons were found per $70-\mu \mathrm{m}$-thick parasagittal section cut through the length of the ipsilateral L3 or L4 segment. Over 100 PSDC cells were examined to determine whether they were $\mathrm{NK} 1$ receptorimmunoreactive, and in all cases it was found that the cells were not immunoreactive (Fig. 1D). Although the outline of cell bodies could be identified, dendritic filling was clearly incomplete; however, primary dendrites could be seen emerging from the cell bodies, and in some cases dendrites could be followed for up to 50 $\mu \mathrm{m}$. Unlike the situation with $\mathrm{NK} 1$ receptor-immunoreactive lamina III/IV neurons, the PSDC cell bodies received few contacts from NPY-immunoreactive varicosities (range of 0-7; $1.40 \pm 0.27$, mean \pm SEM) (Fig. $2 B$ ). When dendrites of PSDC cells were visible, they also received only occasional contacts from NPY-immunoreactive axons, and in no cases were NPYimmunoreactive axons seen running along these dendrites.

Comparison of the data obtained from the neurons selected for quantitative analysis revealed that the density of contacts from NPY-immunoreactive varicosities onto dendrites of NK1 receptor-immunoreactive neurons with cell bodies in laminae III and IV was significantly higher than the density of contacts onto dendrites of lamina I NK1 receptor-immunoreactive neurons ( $p<0.01$; unpaired $t$ test) (Fig. 2A). ANOVA revealed that the number of contacts from NPY-immunoreactive varicosities onto the cell bodies of lamina III/IV NK1 receptor-immunoreactive neurons was also significantly different from that on either lamina I NK1 receptor-immunoreactive neurons or PSDC cells $(p<$ 0.01; Tukey test) (Fig. 2B). 

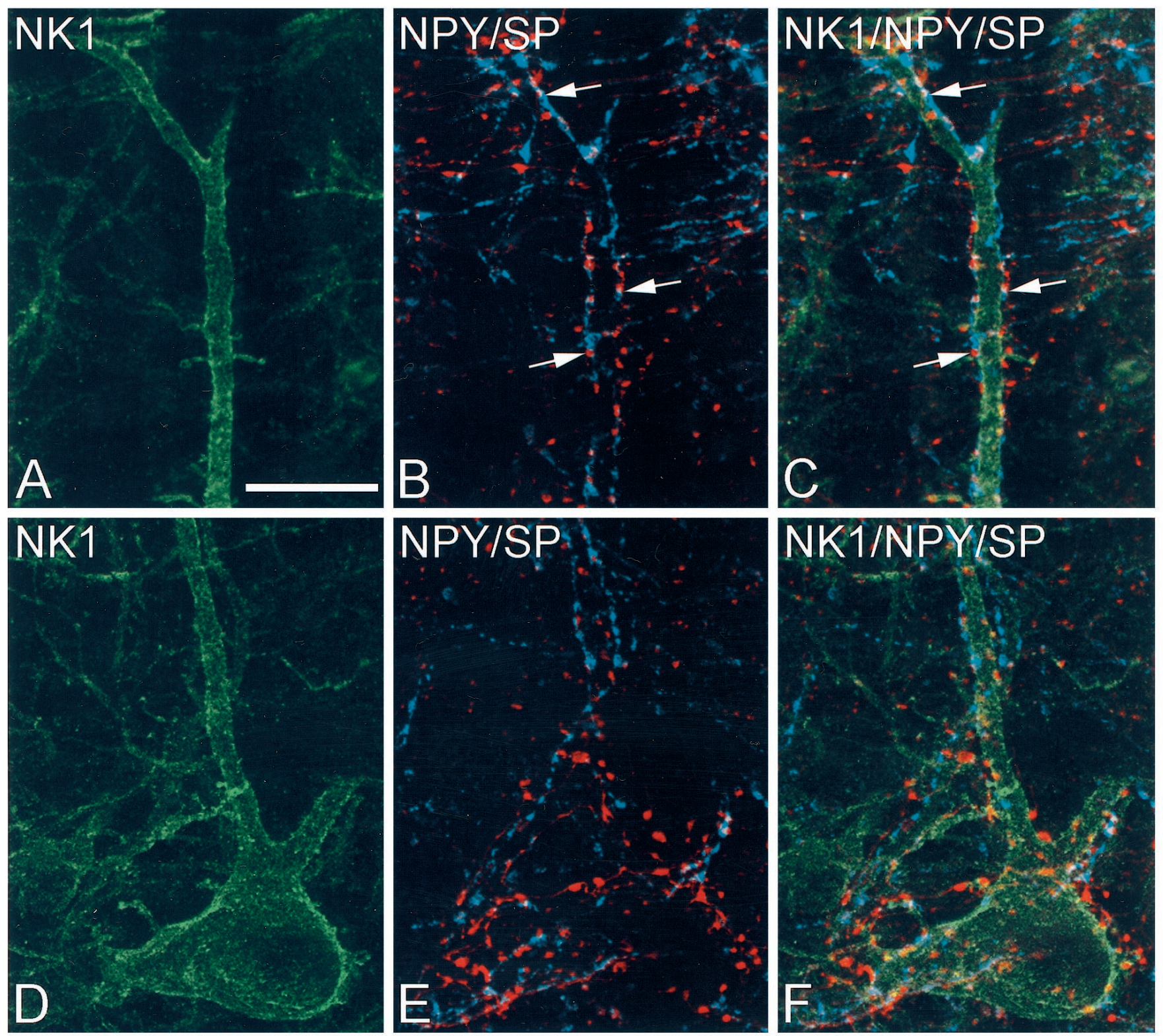

NK1/NPYISP
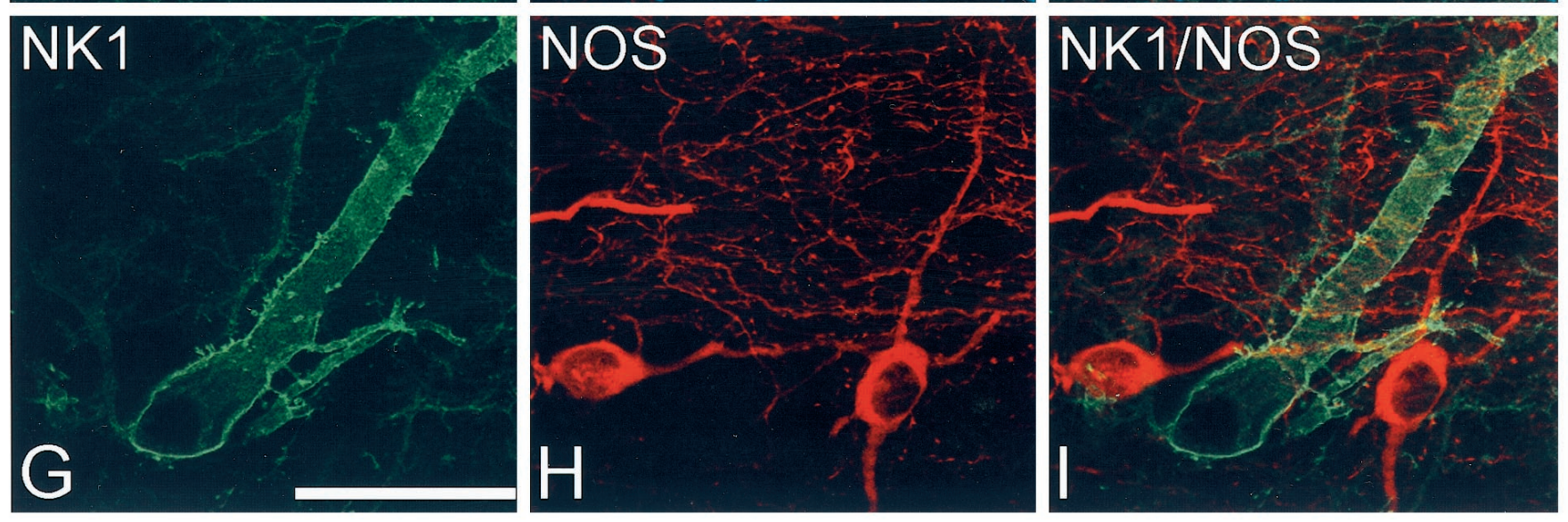

Figure 4. $A-F$ show the cell body $(D-F)$ and a dorsal dendrite $(A-C)$ from a single NK1 receptor-immunoreactive neuron, the cell body of which was in lamina III. $A$ and $D$ show the NK1 receptor immunoreactivity (guinea pig antiserum, green). In $B$ and $E$, the corresponding fields are scanned to reveal NPY (rabbit antiserum, red) and substance P (blue), whereas in $C$ and $F$, the three channels are merged (overlap between red and blue appears white). Although the cell is surrounded and contacted by many NPY- and substance P-immunoreactive varicosities, appositions between varicosities containing NPY and those containing substance P (some of which are indicated with arrows) are not particularly common. G-I show (Figure legend continues) 

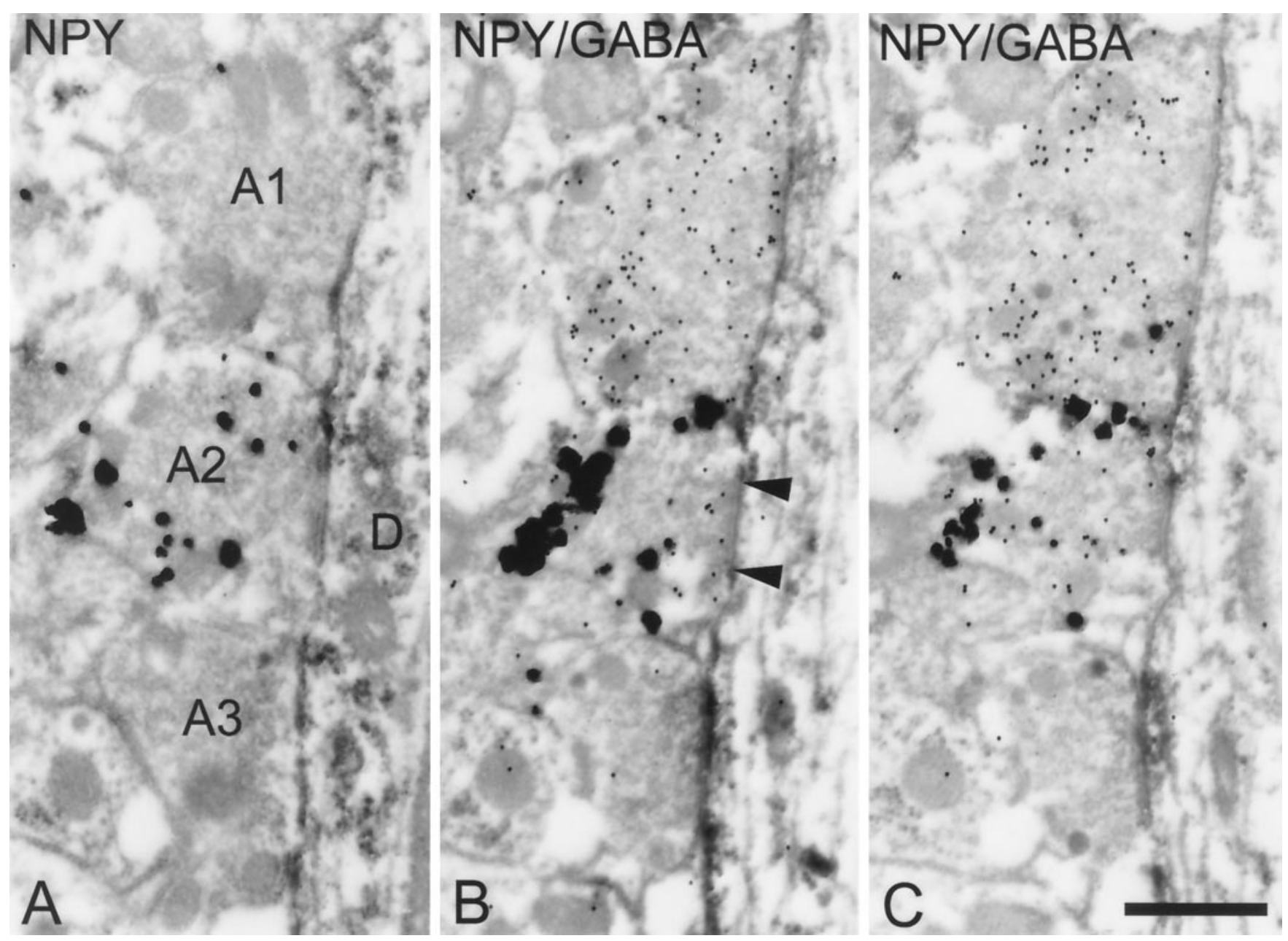

Figure 5. Electron micrographs taken from serial sections, which show three axons $(A 1, A 2$, and $A 3)$ adjacent to the dorsal dendrite of an NK1 receptor-immunoreactive neuron. The dendrite $(D)$ contains DAB reaction product representing the NK1 receptor, whereas one of the axons $(A 2)$ contains numerous silver particles corresponding to NPY immunoreactivity. $A$ is taken from a reference section, and $B$ and $C$ are from consecutive sections on which a postembedding reaction with GABA antiserum was performed; $15 \mathrm{~nm}$ gold particles represent GABA immunoreactivity. $A 1$ is strongly GABAimmunoreactive and $A 2$ is moderately immunoreactive, whereas $A 3$ is not GABA-immunoreactive. The synapse between the NPY-immunoreactive axon and the NK1 receptor-immunoreactive dendrite can be seen on all three sections, and it is indicated between the arrowheads in $B$. Scale bar, $0.5 \mu \mathrm{m}$.

As reported previously (Naim et al., 1997), we found that the lamina III/IV NK1 receptor-immunoreactive neurons received numerous contacts from substance P-immunoreactive varicosities, particularly on their dorsal dendrites (Fig. 4A-F). These were sometimes contacted by NPY-immunoreactive varicosities, but there did not appear to be a specific relationship between the two types of axon, and in most cases varicosities containing one type of peptide immunoreactivity were not in contact with those containing the other (Fig. $4 A-F$ ).

NOS-immunoreactive neurons were present in all dorsal horn laminae, and a plexus of NOS-immunoreactive axons was seen in laminae I and II as described previously (Valtschanoff et al., 1992a; Dun et al., 1993; Spike et al., 1993; Laing et al., 1994). NOS-immunoreactive axons could be distinguished from dendrites because of their beaded appearance. Although dorsal den- drites of NK1 receptor-immunoreactive neurons passed through the plexus of NOS-immunoreactive axons in the superficial dorsal horn (Fig. $4 G-I$ ), they received relatively few contacts. For the six NK1 receptor-immunoreactive neurons studied quantitatively, the density of contacts from NOS-immunoreactive varicosities was between 0.88 and $3.80 / 100 \mu \mathrm{m}(2.18 \pm 0.47$, mean $\pm \mathrm{SEM})$ on dendrites in laminae I and II and between 0.89 and 5.13/100 $\mu \mathrm{m}$ $(2.64 \pm 0.57$, mean \pm SEM $)$ on dendrites in deeper laminae. The cell bodies received between 0 and 6 contacts $(2.33 \pm 0.84$, mean \pm SEM).

\section{Electron microscopy}

Of the 35 NPY-immunoreactive boutons examined, 17 were in contact with the cell body or a dendrite belonging to one of the NK1 receptor-immunoreactive neurons, and 15 of these formed a

the relationship between a lamina III NK1 receptor-immunoreactive neuron (rabbit antiserum, green) and NOS-immunoreactive structures $($ red). In $H$, two NOS-immunoreactive cell bodies, as well as dendrites and a plexus of axons, are visible. The NOS-immunoreactive axons are not specifically associated with the dorsal dendrite of the NK1 receptor-immunoreactive neuron and do not form a cluster around its cell body. $A-C$ were made up from six scans separated by $0.5 \mu \mathrm{m}, D-F$ from eight scans separated by $1 \mu \mathrm{m}$, and $G-I$ from seven scans separated by $0.5 \mu \mathrm{m}$. Scale bars: (in $A$ ) $A-F, 20 \mu \mathrm{m}$; (in $G) G-I, 50 \mu \mathrm{m}$. 
synapse onto the cell (Fig. 5). The remaining 18 boutons were not in contact with the cell but were located within $10 \mu \mathrm{m}$ of it. On 32 of the 35 NPY-immunoreactive boutons (91\%), the density of gold particles representing GABA-like immunoreactivity exceeded the background level by more than a factor of three on both serial sections. However, although these boutons were clearly GABA-immunoreactive, they were never the most strongly immunolabeled for GABA (Fig. $5 B, C$ ).

\section{DISCUSSION \\ NPY and lamina III/IV NK1 receptor-immunoreactive neurons}

The results of this study reveal a very strong association between NPY-containing axons and neurons in lamina III or IV that possess the NK1 receptor and have dendrites that enter the superficial laminae. NPY-containing axons in the dorsal horn are thought to be derived from neurons in laminae I-III (Hökfelt et al., 1981; Hunt et al., 1981; Sasek and Elde, 1985) because the only other known source of NPY in the normal spinal cord is a group of noradrenergic neurons in the rostral ventrolateral medulla that project to the lateral horn in thoracic segments (Blessing et al., 1987), and previous studies have shown that NPY is not colocalized with tyrosine hydroxylase (Blessing et al., 1987) or dopamine $\beta$-hydroxylase (Patel et al., 1997) in the dorsal horn. We have demonstrated previously that all NPY-containing neurons in laminae I-III are GABAergic (Rowan et al., 1993), and the presence of GABA immunoreactivity in the great majority of NPY-immunoreactive boutons strongly supports the view that these axons are derived from local inhibitory interneurons.

To determine whether the innervation of lamina III/IV NK1 receptor-immunoreactive neurons by NPY-containing axons was selective, we also examined the relationship of these axons with NK1 receptor-immunoreactive neurons in lamina I and with PSDC cells. PSDC cells were chosen because they were found not to possess the receptor but nonetheless show certain morphological similarities to the NK1 receptor-immunoreactive neurons: both types have cell bodies in laminae III and IV, and it has been demonstrated in the cat that PSDC cells often have dendrites that enter lamina II (Brown and Fyffe, 1981). Because of limited retrograde filling, we could only examine cell bodies and proximal dendrites of PSDC cells, and we therefore cannot rule out the possibility that the cells may receive contacts from NPYcontaining axons on their distal dendrites. However, the cell bodies and proximal dendrites of the PSDC neurons were never associated with clusters of NPY-immunoreactive axons, unlike those of the lamina III/IV NK1 receptor-immunoreactive neurons. The low frequency of contacts that PSDC cells received from NPY-immunoreactive boutons is unlikely to be caused by a lack of inhibitory axosomatic synapses on these cells, because we have reported previously that PSDC neurons in cat receive numerous axosomatic synapses from GABA- and glycineimmunoreactive boutons (Maxwell et al., 1995). Presumably, the inhibitory inputs to PSDC cells are derived primarily from neurons that do not contain NPY. The lamina I neurons with the NK1 receptor were also found to receive significantly fewer contacts from NPY-containing axons, although their cell bodies and dendrites lie within the dense plexus of NPY-containing axons in laminae I and II.

To test whether the dense innervation of lamina III/IV NK1 receptor-immunoreactive neurons by NPY-containing axons was a feature of other types of inhibitory input to the cells, we examined their association with axons derived from a different population of inhibitory interneurons, those which contain NOS. NOS is largely restricted to GABAergic neurons in the dorsal horn (Valtschanoff et al., 1992b; Spike et al., 1993), and these cells are different from the ones that contain NPY (Laing et al., 1994). Although NOS-containing axons made occasional contacts with the lamina III/IV NK1 receptor-immunoreactive cells, they did not appear to be selectively associated with them. Together, these results suggest that inhibitory circuits in the dorsal horn can be highly organized, with particular types of inhibitory interneuron targeting-specific populations of output cells.

\section{NPY and substance $P$}

We have shown previously that NK1 receptor-immunoreactive neurons in laminae III and IV receive a substantial input from substance P-containing primary afferents (Naim et al., 1997). Because NPY can reduce substance $P$ release (Walker et al., 1988; Duggan et al., 1991) and NPY receptors appear to be present on primary afferents (Bleakman et al., 1991; Kar and Quirion, 1992; Mantyh et al., 1994), we looked for an association between the NPY- and substance P-containing axons that contacted the lamina III/IV NK1 receptor-immunoreactive cells. However, although some contacts between the two types of peptidergic axon were seen, these were never frequent. In addition, quantitative analysis revealed a different distribution of these axons, because contacts from substance P-immunoreactive primary afferents were most numerous on dendrites in laminae I and II (Naim et al., 1997), whereas the density of contacts that the cells received from NPY-immunoreactive axons was significantly higher on dendrites ventral to lamina II, and the neurons received numerous contacts on their cell bodies. This difference in the distribution of NPY- and substance P-containing axons that are associated with the lamina III/IV NK1 receptor-immunoreactive neurons strongly suggests that the cells themselves are a target for the NPY axons, and it is therefore likely that they possess receptors for NPY.

\section{NPY receptors}

Two classes of NPY receptor, $\mathrm{Y}_{1}$ and $\mathrm{Y}_{2}$, have been identified in the spinal cord. $Y_{1}$ immunoreactivity has been found on many small dorsal root ganglion cells but not on their terminals, and in spinal cord it was restricted to a population of neurons in lamina II (Zhang et al., 1994). It is therefore unlikely that NPY acts via $\mathrm{Y}_{1}$ receptors on either the lamina III/IV NK1 receptor-immunoreactive neurons or the associated substance P-containing primary afferent terminals.

Several lines of evidence suggest that $\mathrm{Y}_{2}$ receptors are more significant than $Y_{1}$ receptors in the spinal cord. Binding sites for NPY in spinal cord and dorsal root ganglion are more effectively blocked by $\mathrm{Y}_{2}$ than by $\mathrm{Y}_{1}$ agonists (Mantyh et al., 1994; Zhang et al., 1995), $\mathrm{Y}_{2}$ receptors appear to be responsible for the inhibition of $\mathrm{Ca}^{2+}$ currents in rat dorsal root ganglion cells (Bleakman et al., 1991), and at least part of the anti-nociceptive effect of intrathecal NPY is thought to be mediated by $\mathrm{Y}_{2}$ receptors (Hua et al., 1991). NPY binding sites (most of which appear to represent $\mathrm{Y}_{2}$ receptors) are present at high concentrations in laminae I and II of the dorsal horn, but there is also significant binding in laminae III and IV (Zhang et al., 1995). At present, there are apparently no antibodies against the $\mathrm{Y}_{2}$ receptor; however, in situ hybridization histochemistry has shown that, in addition to labeling of cells in the dorsal root ganglion, there is a low level of $\mathrm{Y}_{2}$ mRNA in laminae I-IV of the dorsal horn (Zhang et al., 1997), which suggests that at least some neurons in these laminae ex- 
press the receptor. Both the NK1 receptor-immunoreactive neurons in laminae III and IV and also their associated substance $\mathrm{P}$-containing primary afferent terminals may therefore possess $\mathrm{Y}_{2}$ receptors; however, this cannot be tested directly until antibodies against the $\mathrm{Y}_{2}$ receptor become available.

Although NPY has been shown to reduce substance P release in vivo in the cat (Duggan et al., 1991), there have been apparently no studies of possible postsynaptic effects on spinal neurons in mammals. In the lamprey spinal cord, NPY-immunoreactive axons (many of which also contain GABA) form close associations with primary afferents (Bongianni et al., 1990). Parker et al. (1998) have recently demonstrated that NPY not only acted presynaptically to reduce the amplitude of primary afferentevoked EPSPs on spinobulbar neurons but also decreased the excitability of these neurons, which was thought to be a postsynaptic action. Spinobulbar neurons in the lamprey appear to be homologous with spinothalamic neurons in mammals, and some of the lamina III/IV NK1 receptor-immunoreactive neurons in the rat belong to this tract (Marshall et al., 1996). It is possible that a dual presynaptic and postsynaptic inhibitory action of NPY also occurs in the rat spinal cord and that this has been highly conserved during evolution.

Although many NPY-containing boutons were in direct contact with the NK1 receptor-immunoreactive neurons, there was often a basket of these boutons that surrounded the cells up to a distance of $\sim 10 \mu \mathrm{m}$ from the cell membrane but nonetheless appeared to be specifically associated with them. If the NK1 receptor-immunoreactive neurons do possess a $\mathrm{Y}$ receptor, this would suggest that NPY acts on these receptors at least partly through volume transmission. The majority of NPY boutons that were apposed to the neurons formed synapses, and these are likely to mediate the parallel GABAergic inhibitory role of the NPY-containing axons. Because lamina III/IV NK1 receptorimmunoreactive neurons also receive some input from myelinated primary afferents, which are likely to be low-threshold mechanoreceptors (Naim et al., 1998), the NPY-containing inhibitory interneurons may also regulate the flow of information conveyed by these afferents.

It has been assumed that the analgesic action of NPY is produced by presynaptic inhibition of nociceptive afferents, particularly those that contain substance P (Walker et al., 1988; Duggan et al., 1991; Hua et al., 1991). The presence of numerous NPY-containing boutons associated with cells in laminae III and IV that possess NK1 receptors and receive monosynaptic input from substance P-containing afferents is compatible with this suggestion, assuming that NPY diff uses from its site of release to influence the substance P-containing terminals. However, the results of the present study suggest that NPY may also act directly on these neurons, and this might therefore contribute to its analgesic effect.

\section{REFERENCES}

Bernardi PS, Valtschanoff JG, Weinberg RJ, Schmidt HHHW, Rustioni A (1995) Synaptic interactions between primary afferent terminals and GABA and nitric oxide-synthesizing neurons in superficial laminae of the rat spinal cord. J Neurosci 15:1363-1371.

Bleakman D, Colmers WF, Fournier A, Miller RJ (1991) Neuropeptide $\mathrm{Y}$ inhibits $\mathrm{Ca}^{2+}$ influx into cultured dorsal root ganglion neurons of the rat via a Y2 receptor. Br J Pharmacol 103:1781-1789.

Bleazard L, Hill RG, Morris R (1994) The correlation between the distribution of $\mathrm{NK}_{1}$ receptor and the actions of tachykinin agonists in the dorsal horn of the rat indicates that substance $\mathrm{P}$ does not have a functional role on substantia gelatinosa (lamina II) neurons. J Neurosci 14:7655-7664.
Blessing WW, Oliver JR, Hodgson AH, Joh TH, Willoughby JO (1987) Neuropeptide Y-like immunoreactive $\mathrm{C}_{1}$ neurons of the rostral ventrolateral medulla of the rabbit project to sympathetic preganglionic neurons in the spinal cord. J Auton Nerv Syst 18:121-129.

Bongianni F, Christenson J, Hökfelt T, Grillner S (1990) Neuropeptide Y-immunoreactive spinal neurons make close appositions on axons of primary sensory afferents. Brain Res 523:337-341.

Brown AG, Fyffe REW (1981) Form and function of dorsal horn neurones with axons ascending the dorsal columns in cat. J Physiol (Lond) 321:31-47.

Brown JL, Liu H, Maggio JE, Vigna SR, Mantyh PW, Basbaum AI (1995) Morphological characterization of substance $P$ receptorimmunoreactive neurons in rat spinal cord and trigeminal nucleus caudalis. J Comp Neurol 356:327-344.

Cuello AC, Galfre G, Milstein C (1979) Detection of substance P in the central nervous system by a monoclonal antibody. Proc Natl Acad Sci USA 76:3532-3536.

Doyle CA, Maxwell DJ (1994) Light- and electron-microscopic analysis of neuropeptide Y-immunoreactive profiles in the cat spinal dorsal horn. Neuroscience 61:107-121.

Duggan AW, Hope PJ, Lang CW (1991) Microinjection of neuropeptide $\mathrm{Y}$ into the superficial dorsal horn reduces stimulus-evoked release of immunoreactive substance $\mathrm{P}$ in the anaesthetized cat. Neuroscience 44:733-740.

Dun NJ, Dun SL, Wu SY, Forstermann U, Schmidt HHHW, Tseng LF (1993) Nitric oxide synthase immunoreactivity in the rat, mouse, cat and squirrel monkey spinal cord. Neuroscience 54:845-857.

Gibson SJ, Polak JM, Allen JM, Adrian TE, Kelly JS, Bloom SR (1984) The distribution and origin of a novel brain peptide, neuropeptide $\mathrm{Y}$, in the spinal cord of several mammals. J Comp Neurol 227:78-91.

Herbison AE, Simonian SX, Norris PJ, Emson PC (1996) Relationship of neuronal nitric oxide immunoreactivity to GnRH neurons in the ovariectomized and intact female rat. J Neuroendocrinol 8:73-82.

Hökfelt T, Lundberg JM, Terenius L, Jancso G, Kimmel J (1981) Avian pancreatic polypeptide (APP)-immunoreactive neurons in the spinal cord and trigeminal nucleus. Peptides 2:81-87.

Hua X-Y, Boublik JH, Spicer MA, Rivier JE, Brown MR, Yaksh TL (1991) The anti-nociceptive effects of spinally administered neuropeptide $\mathrm{Y}$ in the rat: systematic studies on structure-activity relationship. J Pharmacol Exp Ther 258:243-248.

Hunt SP, Kelly JS, Emson PC, Kimmel JR, Miller RJ, Wu J-Y (1981) An immunohistochemical study of neuronal populations containing neuropeptides or $\gamma$-aminobutyrate within the superficial layers of the rat dorsal horn. Neuroscience 6:1883-1898.

Kar S, Quirion R (1992) Quantitative autoradiographic localization of $\left[{ }^{125}\right.$ I]neuropeptide $\mathrm{Y}$ receptor binding sites in rat spinal cord and the effects of neonatal capsaicin, dorsal rhizotomy and peripheral axotomy. Brain Res 574:333-337.

Krukoff TL (1987) Neuropeptide Y-like immunoreactivity in cat spinal cord with special reference to autonomic areas. Brain Res 415:300-308.

Laing I, Todd AJ, Heizmann CW, Schmidt HHHW (1994) Subpopulations of GABAergic neurons in laminae I-III of rat spinal dorsal horn defined by coexistence with classical transmitters, peptides, nitric oxide synthase or parvalbumin. Neuroscience 61:123-132.

Lawson SN, Crepps BA, Perl ER (1997) Relationship of substance P to afferent characteristics of dorsal root ganglion neurones in guinea-pig. J Physiol (Lond) 505:177-191.

Littlewood NK, Todd AJ, Spike RC, Watt C, Shehab SAS (1995) The types of neuron in spinal dorsal horn which possess neurokinin-1 receptors. Neuroscience 66:597-608.

Liu H, Brown JL, Jasmin L, Maggio JE, Vigna SR, Mantyh PW, Basbaum AI (1994) Synaptic relationship between substance P and the substance $\mathrm{P}$ receptor: light and electron microscopic characterization of the mismatch between neuropeptides and their receptors. Proc Natl Acad Sci USA 91:1009-1013.

Llewellyn-Smith IJ, Minson JB (1992) Complete penetration of antibodies into vibratome sections after glutaraldehyde fixation and ethanol treatment: light and electron microscopy for neuropeptides. J Histochem Cytochem 40:1741-1749.

Mantyh PW, Allen CJ, Rogers S, DeMaster E, Ghilardi J, Mosconi T, Kruger L, Mannon PJ, Taylor IL, Vigna SR (1994) Some sensory neurons express neuropeptide $\mathrm{Y}$ receptors: potential paracrine inhibition of primary afferent nociceptors following peripheral nerve injury. J Neurosci 14:3958-3968.

Marshall GE, Shehab SAS, Spike RC, Todd AJ (1996) Neurokinin-1 
receptors on lumbar spinothalamic neurons in the rat. Neuroscience 72:255-263.

Maxwell DJ, Todd AJ, Kerr R (1995) Colocalization of glycine and GABA in synapses on spinomedullary neurons. Brain Res 690:127-132.

Naim M, Spike RC, Watt C, Shehab SAS, Todd AJ (1997) Cells in laminae III and IV of the rat spinal cord that possess the neurokinin-1 receptor and have dorsally directed dendrites receive a major synaptic input from tachykinin-containing primary afferents. J Neurosci 17:5536-5548.

Naim MM, Shehab SAS, Todd AJ (1998) Cells in laminae III and IV of the rat spinal cord which possess the neurokinin-1 receptor receive monosynaptic input from myelinated primary afferents. Eur J Neurosci 10:3012-3019.

Nakaya Y, Kaneko T, Shigemoto R, Nakanishi S, Mizuno N (1994) Immunohistochemical localization of substance $\mathrm{P}$ receptor in the central nervous system of the adult rat. J Comp Neurol 347:249-274.

Parker D, Söderberg C, Zoltova E, Shupliakov O, Langel U, Bartfai T, Larhammar D, Brodin L, Grillner S (1998) Co-localized neuropeptide $\mathrm{Y}$ and GABA have complementary presynaptic effects on sensory synaptic transmission. Eur J Neurosci 10:2856-2870.

Patel R, Kerr R, Maxwell DJ (1997) Absence of co-localized glutamate decarboxylase and neuropeptides in noradrenergic axons of the rat spinal cord. Brain Res 749:164-169.

Pow DV, Crook DK (1993) Extremely high titre polyclonal antisera against small neurotransmitter molecules: rapid production, characterisation and use in light- and electron-microscopic immunocytochemistry. J Neurosci Methods 48:51-63.

Ribeiro-da-Silva A, Coimbra A (1982) Two types of synaptic glomeruli and their distribution in laminae I-III of the rat spinal cord. J Comp Neurol 209:176-186.

Rowan S, Todd AJ, Spike RC (1993) Evidence that neuropeptide Y is present in GABAergic neurons in the superficial dorsal horn of the rat spinal cord. Neuroscience 53:537-545.

Sasek CA, Elde RP (1985) Distribution of neuropeptide Y-like immunoreactivity and its relationship to FMRF-amide-like immunoreactivity in the sixth lumbar and first sacral spinal cord segments of the rat. J Neurosci 5:1729-1739.
Spike RC, Todd AJ, Johnston HM (1993) Coexistence of NADPH diaphorase with GABA, glycine and acetylcholine in rat spinal cord. J Comp Neurol 335:320-333.

Todd AJ (1996) GABA and glycine in synaptic glomeruli of the rat spinal dorsal horn. Eur J Neurosci 8:2492-2498.

Todd AJ, Watt C, Spike RC, Sieghart W (1996) Colocalization of GABA, glycine, and their receptors at synapses in the rat spinal cord. J Neurosci 16:974-982.

Valtschanoff JG, Weinberg RJ, Rustioni A (1992a) NADPH diaphorase in the spinal cord of rats. J Comp Neurol 321:209-222.

Valtschanoff JG, Weinberg RJ, Rustioni A, Schmidt HHHW (1992b) Nitric oxide synthase and GABA colocalize in lamina II of rat spinal cord. Neurosci Lett 148:6-10.

Vigna SR, Bowden JJ, McDonald DM, Fisher J, Okamoto A, McVey DC, Payan DG, Bunnett NW (1994) Characterization of antibodies to the rat substance $\mathrm{P}(\mathrm{NK}-1)$ receptor and to a chimeric substance $\mathrm{P}$ receptor expressed in mammalian cells. J Neurosci 14:834-845.

Walker MW, Ewald DA, Perney TM, Miller RJ (1988) Neuropeptide Y modulates neurotransmitter release and $\mathrm{Ca}^{2+}$ currents in rat sensory neurons. J Neurosci 8:2438-2446.

Xu X-J, Hao J-X, Hökfelt T, Wiesenfeld-Hallin Z (1994) The effects of intrathecal neuropeptide $\mathrm{Y}$ on the spinal nociceptive flexor reflex in rats with intact sciatic nerves and after peripheral axotomy. Neuroscience 63:817-826.

Zhang X, Bao L, Kopp J, Arvidsson U, Elde R, Hökfelt T (1994) Localization of neuropeptide Y Y1 receptors in the rat nervous system with special reference to somatic receptors on small dorsal root ganglion neurons. Proc Natl Acad Sci USA 91:11738-11742.

Zhang X, Ji R-R, Nilsson S, Villar M, Ubink R, Ju G, Wiesenfeld-Hallin Z, Hökfelt T (1995) Neuropeptide $\mathrm{Y}$ and galanin binding sites in rat and monkey dorsal root ganglia and spinal cord and effect of peripheral axotomy. Eur J Neurosci 7:367-380.

Zhang X, Shi T, Holmberg K, Landry M, Huang W, Xiao H, Ju G, Hökfelt T (1997) Expression and regulation of the neuropeptide Y Y2 receptor in sensory and autonomic ganglia. Proc Natl Acad Sci USA 94:729-734 